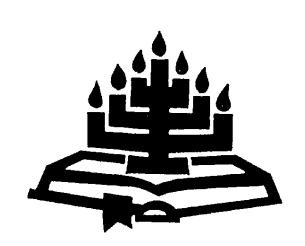

\title{
Romeine 1:18-25 binne die openbarings- historiese raamwerk van die Skrifgetuienis aangaande God se openbaring
}

\author{
G.J.C. Jordaan \\ Skool vir Bybelwetenskappe en Bybeltale \\ Potchefstroomse Universiteit vir $\mathrm{CHO}$ \\ POTCHEFSTROOM \\ E-pos: sbbgjcj@puknet.puk.ac.za
}

\begin{abstract}
Romans 1:18-25 within the revelational-historical framework of Scriptural evidence about God's revelation

In this article the central issue investigated is whether - since the time of creation - man has been able to know God sufficiently in order to receive His saving faith. For this purpose a revelationalhistorical study of Romans 1:18-25 is undertaken in an attempt to contribute to this debate. Central themes from Romans 1:18-25 are also analysed and related to passages with a similar content elsewhere in Romans and also throughout the entire Bible. In this process not only the immediate context of each passage is taken into account, but also its place and meaning within the growing line of God's revelation in Scripture. The conclusion arrived at is that God's revelation in creation as such is sufficient to bring man to a saving faith. However, man's perception and understanding are so corrupted by sin that it is impossible for any human being to receive saving faith only by perceiving and interpreting God's revelation in creation. Therefore God has given His revelation in Scripture to bring mankind to saving faith.
\end{abstract}

\section{Opsomming}

Romeine 1:18-25 binne die openbaringshistoriese raamwerk van die Skrifgetuienis aangaande God se openbaring

In hierdie artikel is die sentrale vraag of die mens - sedert die tyd van die skepping - God genoegsaam uit die skepping kan leer ken om tot reddende geloof te kom. Vir hierdie doel word 'n openbaringshistoriese ondersoek van Romeine 1:18-25 onderneem in ' $n$ poging om by te dra tot die gesprek. Sentrale temas uit Romeine 
1:18-25 word ontleed en vergelyk met gedeeltes wat handel oor soortgelyke sake, elders in Romeine self en ook dwarsdeur die Bybel. Met hierdie proses word nie net die onmiddellike konteks van elke Skrifdeel in aanmerking geneem word nie, maar ook die plek daarvan binne die groeiende lyn van God se openbaring in die Skrif. Dit lei tot die gevolgtrekking dat God se skeppingsopenbaring genoegsaam is om die mens tot reddende geloof te bring. Die mens se waarneming en begrip daarvan is egter so deur die sonde aangetas dat dit vir enige mens onmoontlik is om slegs deur sy waarneming en vertolking van die skeppingsopenbaring tot reddende geloof te kom. Daartoe het elke mens God se openbaring wat Hy in die Skrif gegee het, nodig.

\section{Inleiding}

\subsection{Agtergrond, probleemstelling en doel}

Die huidige debat oor multi-religieusiteit het die vraag oor Godskennis baie aktueel gemaak. Veral in die branding is die vraag of mense sonder dat hulle die evangelie gehoor het, bloot op grond van God se skeppingsopenbaring, ${ }^{1}$ God in die geloof kan ken. Binne hierdie debat neem Romeine 1:18-25 'n baie belangrike plek in. Trouens, reeds in artikel 2 van die Nederlandse Geloofsbelydenis (NGB), waar dit juis gaan oor die middele waardeur God geken word, is Romeine 1:20 die eerste (en enigste) Skrifgrond wat aangehaal word.

Onder verklaarders bestaan daar egter nie eenstemmigheid oor wat hierdie perikoop presies oor die verhouding tussen openbaring en kennis van God sê nie. Kruger (2000b:4) verwerp byvoorbeeld Ridderbos (1959:43) se verklaring van Romeine 1:20 dat die skeppingsopenbaring die mens sonder verontskuldiging laat (vgl. ook Sanday \& Headlam, 1911:44; Greijdanus, 1933:111). Hierteenoor stel Kruger dat die skeppingsopenbaring aldus Romeine 1:18-25 genoegsaam is om die mens tot reddende geloof te bring, maar dat die mens dit moedswillig en hardkoppig verwerp het (Kruger, 2000a:45; vgl. ook Käsemann, 1980: 41). Fitzmeyer (1993:273), in aansluiting by Moo (1991:99) is oortuig dat, volgens Romeine 1:20, God Homself in die skepping wel kenbaar maak ( $\phi \alpha \nu \in \rho o v \nu$ ), maar dat Hy Homself slegs deur die evangelie genoegsaam

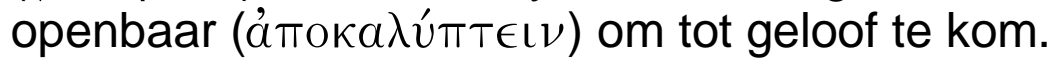

Hierdie meningsverskille hou moontlik verband met verskillende benaderingshoeke tot die perikoop. Metodologies gesproke, is Romeine skepping, onderhouding en regering van alle dinge" (NGB artikel 2) kortweg verwys as "God se skeppingsopenbaring". 
1:18-25 tot dusver hoofsaaklik bestudeer vanuit 'n grammatiese analise (bv. Sanday \& Headlam, 1911:44; Greijdanus, 1933:107-111; Ridderbos, 1959:42-44), vanuit 'n stilistiese en sosiohistoriese analise (bv. Käsemann, 1980:360-45) of vanuit 'n epistolografiese en strukturele analise (bv. Kruger, 2000a:8 e.v.)2 'n Behoefte wat egter bestaan - en hierdie artikel is daarop gerig om aan die behoefte inhoud te gee - is dat die perikoop binne die omvattende openbaringshistoriese lyne van die Skrif bestudeer word.

Die doel van hierdie artikel is om 'n openbaringshistoriese ondersoek van die perikoop Romeine 1:18-25 te doen ten einde lig te kry op die volgende vrae:

- Waartoe lei God se skeppingsopenbaring - tot kennis van God self of ook tot saligmakende geloof?

- Dien die skeppingsopenbaring bloot daartoe dat die mens geen verontskuldiging voor God het nie?

- Het die mens iets meer as net die skeppingopenbaring nodig (met ander woorde: ook die Woordopenbaring) om tot saligmakende geloof te kom?

\subsection{Metode van openbaringshistoriese ondersoek}

'n Openbaringshistoriese ondersoek beteken dat 'n teks nie net binne die konteks van die boek waarvan dit deel vorm, gelees word nie, maar ook binne die konteks van die res van die Bybel. Die prinsipiële standpunt is dat die 66 Bybelboeke, almal die Heilige Gees as Auctor Primarius het en daarom as Woord van God tot 'n eenheid saamgebind is (vgl. Kuyper, 1909:166-180). (Hierdie standpunt erken egter ook dat elke Bybelboek ten opsigte van 'n verskeidenheid faktore eiesoortig is.) 'n Openbaringshistoriese studie analiseer die opbou en struktuur van die Skrifboodskap - in eenheid én diversiteit (Ridderbos, 1982:174).

Coetzee (1995b:34) definieer openbaringshistoriese studie soos volg:

History of revelation is the theological discipline which focuses on the study of the meaning of the Scripturally revealed acts of God in history in their mutual cohesion, and to the scientific description of their total-proclamation and /or total preaching - both in their historical progress and by way of in-depth-incisions into central themes of the God-revelation.

2 Enkele van hierdie benaderings word in artikels elders in hierdie bundel wel onder oë geneem. 
Hieraan gemeet, sou 'n studie van Romeine 1:18-25 binne die openbaringshistoriese lyne van die Skrif, rekening moet hou met die volgende:

- Die wyse waarop die perikoop saamhang met ander verwante Skrifgeopenbaarde werke van God, dit wil sê Skriftemas wat verwant is aan die perikooptemas, kortom: verwante kerntemas.

- Die plek wat die perikoop inneem in die groeiende openbaringshistoriese lyn van verwante temas in die Skrif.

- Hoe die Skriftemas saam met die openbaringsinhoud van die perikoop tot 'n geheelbeskrywing saamgevat moet word.

Ridderbos (1982:189) se beskouing van die taak van openbaringshistoriese ondersoek sluit hierby aan, naamlik dat bepaalde teologiese onderwerpe in een of meer geskrifte bestudeer moet word met inagneming van die groeiende lyn waarop die kerugma van die Nuwe Testament ontvou vanuit die verskillende benaderingshoeke van die onderskeie Bybelboeke.

Binne bogenoemde metodologiese raamwerk word Romeine 1:18-25 dan in hierdie artikel as voorwerp van openbaringshistoriese ondersoek geneem.

\section{Kerntemas in Romeine 1:18-32}

Die ontleding van die gedagtestruktuur deur Viljoen (artikel elders in hierdie bundel) en die retoriese analise van Cornelius (artikel elders in hierdie bundel) is geneem as vertrekpunt vir die bepaling van die perikoop se kerntemas. Hierby is ook enkele sentrale begrippe wat deur Kruger (2002a) uitgewys is, bygewerk. Sodoende is die volgende perikooptemas in Romeine 1:18-25 uitgesonder:

- God maak die waarheid aangaande Homself bekend (openbaar dit) in sy werke.

- Mense onderdruk die geopenbaarde waarheid aangaande God.

- Aangesien God die waarheid duidelik kenbaar maak, is daar vir mense wat dit onderdruk geen verontskuldiging nie.

- God is vertoorn oor en straf diegene wat die waarheid aangaande Hom onderdruk.

In die uiteensetting wat volg oor die voorkoms van verwante temas elders in Romeine en in die res van die Skrif word veral op die voorkoms van hierdie kerntemas gefokus. 


\section{Samehang met verwante dele elders in Romeinebrief}

\subsection{Romeine 1:18-32 binne die gedagtestruktuur van die Romeinebrief}

Oor die hoofindeling van die Romeinebrief is daar onder hedendaagse biblioloë redelike eenstemmigheid (Fitzmeyer; 1993:96-97): 1:1-17 bevat die briefinleiding; 2:18-4:25 is die eerste hoofdeel en 'n uitbouing van die tema regverdigmaking deur die geloof ; 5:1-8:39 is die tweede hoofdeel waarin die gevolge van regverdigmaking deur die geloof uitgespel word; 9:1-11:36 is die derde hoofdeel wat op die Jode en die heidene fokus; die vierde hoofdeel (12:1-15:13) bevat die paraklese van die brief en 15:14-16:27 is die briefslot.

Ridderbos (1959:19) se aanwys van Romeine 1:16-17 as die sentrale tema van die Romeinebrief word oor die algemeen deur verklaarders gedeel (vgl. Coetzee, 1995a:48). Die brieftema kan geformuleer word as regverdiging deur die geloof (vgl. ook Kruger (2000a:8). Dit blyk dat hierdie brieftema in die eerste twee hoofdele van die brief $(1: 16-8: 39)$ op 'n besondere manier klimakties uitgebou word. Die klimaktiese uitbouing bestaan daarin dat twee basiese fasette uit die tema geneem word en dan op interaktiewe wyse langs mekaar tot by 'n hoogtepunt ontplooi word. Die twee fasette is:

- Alle mense (Jode sowel as nie-Jode) het God se redding nodig (1:16: " ... 'n krag van God tot redding vir elkeen wat glo, eerste vir die Jood en ook vir die Griek").

- God laat die redding in Christus gestalte kry, deur regverdigmaking slegs langs die weg van geloof (1:16: "... evangelie van Christus"; 1:17: "Want die geregtigheid van God word daarin geopenbaar uit geloof tot geloof") 3 .

Hierdie twee fasette van die brieftema word dan in twee parallelle lyne ontplooi. Die openbaringshistoriese uitbouing van die brieftema in twee lyne kan skematies soos volg voorgestel word (die grys dele stel die donker lyn van die sonde-ellende van die mens voor; die wit dele daarteenoor stel die lyn van die lig van God se genade voor):

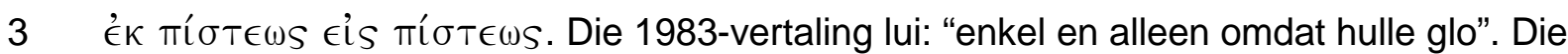
voorsetselfrase sou myns insiens beter weergegee kon word as "geheel en al langs die weg van die geloof" (vgl. Louw \& Nida, 1988:692). 


\section{1:16-17 Brieftema:}

Alle mense (Jode en Grieke) het God se redding nodig.

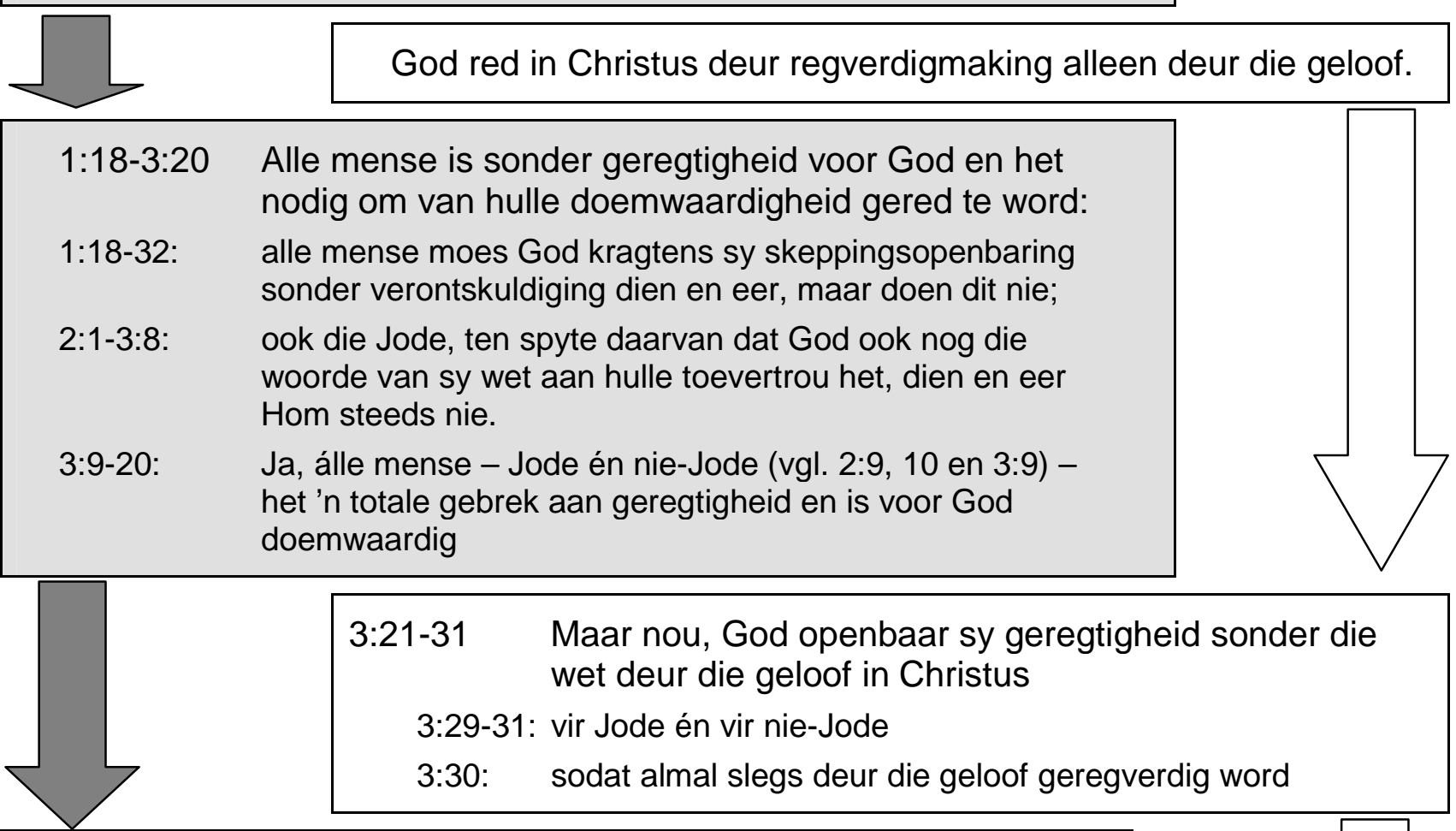

4:1-25 Let wel, Jode: Selfs Abraham het sonder enige verdienste alleen langs die weg van die geloof geregtigheid van God ontvang

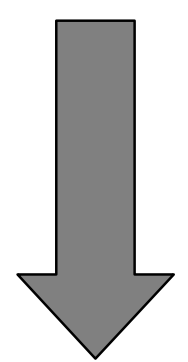

5:1-21 Wat behels die regverdigmaking deur die geloof?

5:1-11 Inhoudelik: Die geregtigheid wat ons deur die geloof in Christus ontvang, bring vrede en versoening met God.

5:12-21Wyse: God het ons regverdig gemaak deurdat Christus die sonde waaraan alle mense van Adamsweë skuldig staan, op Hom geneem het.

6:1-7:26 Die sonde is so deel van die mens dat ons, selfs as verlostes en geregverdigdes, lewenslank teen die kwaad in ons moet bly stry.

Klimaks:

8:1-39 Regverdigmaking deur die geloof beteken dat daar dan nou geen veroordeling is vir die wat in Christus Jesus is nie!

8:1-17 Die krag van die Heilige Gees bestry die sonde in ons.

8:18-30 God lei ons langs sy (heilsordelike) weg van lyding na heerlikheid.

8:31-39 Oorwinningslied van die geloof: In Christus geregverdig, sal niks ons meer van God se liefde skei nie! 
Die lyn van regverdigmaking deur die geloof word dan vanaf die openbaringshistoriese klimaks in hoofstuk 8 verder in die brief uitgebou. In hoofstukke 9-11, die derde hoofdeel, word verduidelik hoe dit werk dat sowel Jode as nie-Jode die geregtigheid deur die geloof ontvang. Opvallend is dat hierdie hoofdeel, net soos die tweede, ook met 'n loflied eindig (11:33-36). In hoofstukke 12:1 - 15:13 volg die paraklese oor hoe dié wat deur die geloof geregverdig is, moet lewe.

Binne hierdie openbaringshistoriese raamwerk van die Romeinebrief vorm die perikoop 1:18-25 die vertrekpunt waaruit verduidelik word dat alle mense sonder geregtigheid voor God is en daarom heeltemal doemwaardig is. Teen die agtergrond van hierdie raamwerk kan die verloop van die perikoop se kerntemas dan verder in die Romeinebrief bekyk word.

\subsection{Kerntemas van Romeine 1:18-32 elders in Romeinebrief}

By wyse van 'n studie van tersaaklike vakliteratuur en 'n konkordansiesoektog is die voorkoms van 1:18-25 se kerntemas (vgl. afdeling 2) elders in die Romeinebrief nagespeur. Die resultate daarvan word dan in verband gestel met die eksegetiese detail van Romeine 1:18-25.

\subsubsection{God maak die waarheid aangaande Homself bekend}

\subsubsection{Dit wat God aangaande Homself kenbaar maak}

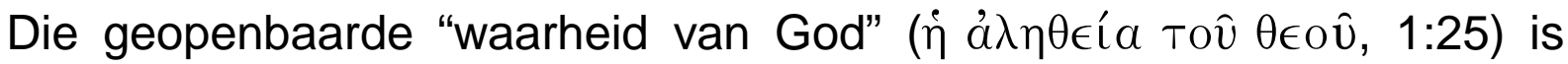
volgens Romeine 1:20 sy onsigbare "eienskappe" ( $\tau a ̀$ ảópata, naamlik

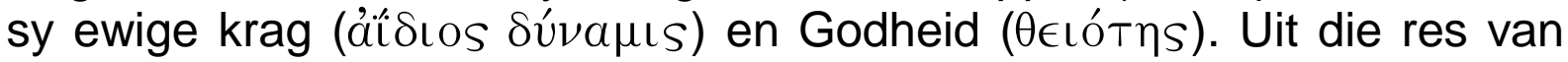
die perikoop blyk dit egter dat die openbaring nie net op kennis van God se onsigbare eienskappe gerig is nie, maar dat dit mense op grond van die kennis ook tot optrede wil bring, naamlik dat hulle God verheerlik en dank (1:21).

Hierdie vermoede word bevestig deur Romeine 2:13, waar ter vermaning aan die Jode gesê word dat nie die hoorders van die wet nie, maar die daders van die wet geregverdig word. Dat daardie optrede spesifiek 'n uiting van eer en dank aan God moet wees, blyk verder uit die lofsang waarmee die derde hoofdeel van die brief afsluit (Rom. 11:33-36). Die uitroep waarmee die lofsang in Romeine 11:33 begin ("O, diepte van die rykdom en wysheid en kennis van God!"), sluit aan by die kennis-tema. Dat dit gaan oor kennis van die onsienlike dinge (die áópata) van God, blyk uit vers 34: "Hoe ondeurgrondelik is sy oordele en onnaspeurlik sy weë". Vers 26 sluit aan by die tema van "eer aan God: "Aan Hom behoort die heerlikheid tot in ewigheid". So blyk dit dat die tema van eer 
en dank aan God vanaf Romeine 1:21 'n groeiende lyn volg tot by 11:3336.

God openbaar egter ook die manier waarop eer en dank aan Hom bewys moet word. In Romeine 1:18-25 word die wyse van eer en dank nie uitdruklik genoem nie maar slegs die keersy daarvan, naamlik godde-

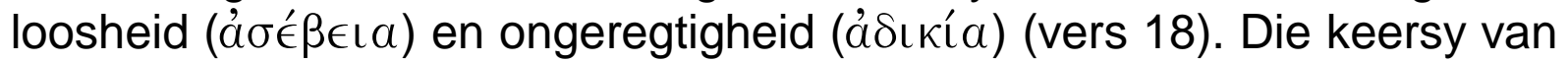

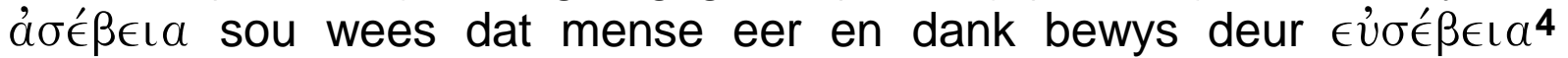
oftewel $\delta \in \iota \sigma \iota \delta a \iota \mu o v i a^{5}$ te betoon. In die Romeinebrief word egter nóg $\epsilon \dot{v} \sigma \epsilon ́ \beta \epsilon \iota a$ nóg $\delta \in \iota \sigma \iota \delta a \iota \mu o \nu$ ía nóg 'n ander verwante woord uit dieselfde semantiese subdomein gebruik (53A "Religious practice"; vgl. Louw \&

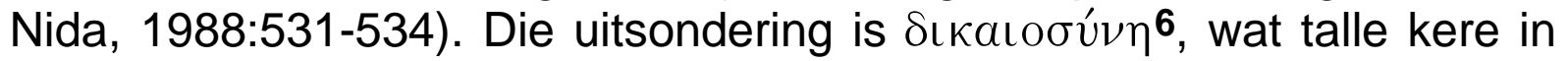

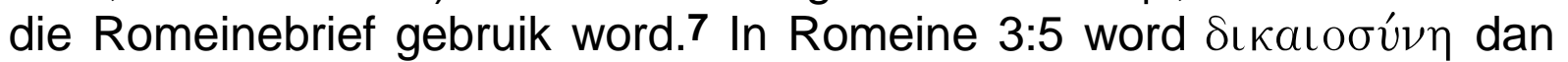

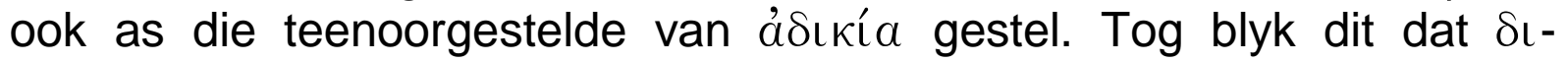

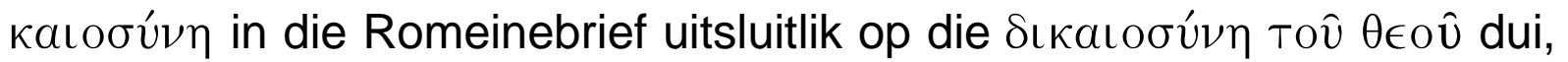
dit wil sê die daad van regverdigmaking deur God (vgl. Coetzee, 1995a:48).

Nogtans word die gedagte dat God deur vroom optrede vereer moet word, verder in die brief uitgebou. Aanvanklik ontplooi die lyn steeds by wyse van verwysing na negatiewe optrede, soos in Romeine 2:23, waar

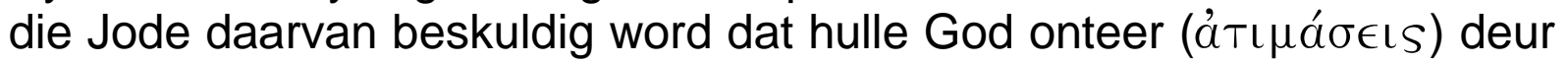
die wet te oortree. In Romeine 3:23 word dieselfde saak effens anders gestel, maar word hierdie keer nie net op die Jode toegepas nie, maar op alle mense (vgl. Greijdanus, 1933:191; Murray, 1959:112; Fitzmeyer, 1993:346): "Almal het gesondig en dit ontbreek hulle aan die heerlikheid

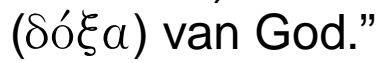

In Romeine 1:25 word egter 'n nuwe woord gebruik wat die skakel vorm met die verdere uitbouing van die tema: die mense vereer en dien ('̇ $\lambda a ́ T \rho \in v \sigma \alpha \nu)$ skepsele in plaas van God. Dit beteken dat God deur aanbidding $\left(\lambda a \tau \rho \in \epsilon^{\prime} \alpha\right)$ vereer moet word.8 Hierdie gedagte word verder gevoer in Romeine 9:4, waar Paulus skrywe dat God met Israel "die verbonde gesluit (het) en die wet gegee (het) en die manier waarop Hy

4 "Vroomheid", "godsvrug", "'n lewe soos God dit wil hê", vgl. domein 53.5 en 53.6 in Louw en Nida (1988:532).

5 "Geloofsoortuigings aangaande die Godheid met ooreenstemmende gedrag"; vgl. domein 53.2 en 53.3 in Louw en Nida (1988:532).

$6 \quad$ "Reg-doen as godsdienstige vereiste"; vgl. 53.4 in Louw en Nida (1988:532).

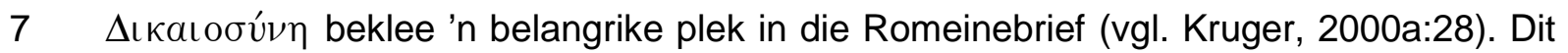
kom nie minder nie as 30 keer in die brief voor. 
aanbid moet word ( $\dot{\eta} \lambda \alpha \tau \rho \epsilon i ́ a)$ ). 9 Romeine 12:1, die beginpunt van die paraklese-deel van die brief, bied 'n verdere ontplooiing van die $\lambda a \tau \rho \in$ ía-motief. In Romeine 12:1 gaan dit oor die wesentlike $\lambda a \tau \rho \in i ́ a$ wat God van dankbare geregverdigdes verwag (vgl. Schlier, 1977:354; Mounce, 1995:231). Uit Romeine 12:2 word dit dan duidelik dat die gelowiges moet kan "onderskei wat die wil van God is, wat vir Hom goed en aanneemlik" is. Die $\lambda a \tau \rho \in$ ía bestaan dan daarin dat dit wat vir God aanneemlik is, gedoen word (vers 1).

Samevattend blyk dit dat die onsigbare dinge wat God aangaande Homself kenbaar maak, begin by sy ewige krag en Godheid, dit wil sê dat Hy die almagtige God is. Daarby hou dit egter nie op nie. Hy maak ook bekend dat elkeen wat Hom in sy krag en Godheid leer ken het, aan Hom eer en dank verskuldig is. Verder maak Hy ook bekend hoe die eer en dank aan Hom bewys moet word, naamlik dat $\mathrm{Hy}$ in aanbidding gedien moet word. Uiteindelik maak Hy aan die mense bekend hoe Hy gedien moet word, naamlik deur te doen wat vir Hom goed en aanneemlik is. In al hierdie opsigte is God kenbaar ( $\gamma \nu \omega \sigma \tau o ́ \nu)$ in sy skeppingsopenbaring (vgl. Cranfield, 1985:113).

\subsubsection{Die manier waarop God Homself bekend maak}

Romeine 1:18-25 het sy wye bekendheid ongetwyfeld aan die inhoud van vers 20 te danke: "Sy onsigbare dinge kan van die skepping van die

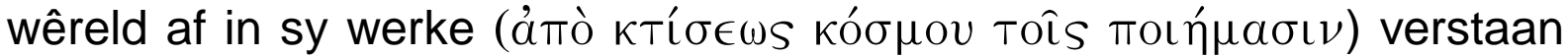
en duidelik gesien word." Verklaarders (bv. Murray, 1959:39; Black, 1973:50; Cranfield, 1985:114; Dunn, 1988:58; Fitzmeyer, 1993:280;

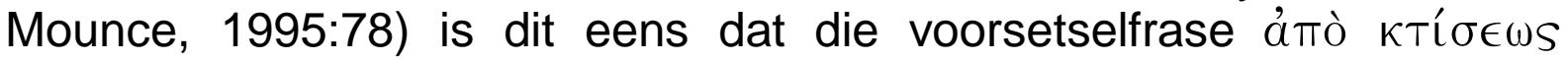
Kó $\sigma \mu \mathrm{ov}$ as 'n tydsbepaling beskou moet word, met ander woorde: "van die skepping af tot vandag toe".10 Die wyse waarop of die instrument waarmee God Homself kenbaar maak, word gestel deur die datief Toîs moıń $\mu \alpha \sigma \iota \nu$ ("in/deur sy werke"). Wat daardie werke van God is, word nie in Romeine 1:20 of verder in die Romeinebrief spesifiek vermeld nie. Die enigste moontlike aansluiting word gevind in Romeine 11:36: "Uit Hom en deur Hom en tot Hom is alle dinge", wat volgens Calvyn (vgl. Calvijn, 1950:371-372) en Mounce (1995:227) dui op die skepping ("uit Hom"), onderhouding ("deur Hom") en regering ("tot Hom")

9 Die 1933/53-vertaling vertolk dit as "erediens" en die 1983-vertaling as "tempeldiens". Tereg so, maar dit gaan steeds oor hoe God wil hê dat Hy aanbid moet word.

10 Daarom kan die term "skeppingsopenbaring" wat bondigheidshalwe in hierdie artikel gebruik word, misleidend wees. Dit mag die indruk gee dat God in Romeine 1:20 sê dat

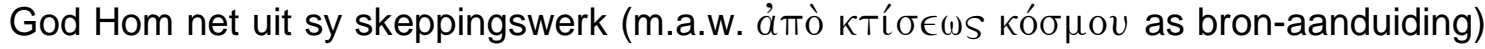
kenbaar maak. 
van alle dinge. Of dít werklik die bedoeling van Romeine 11:36 is, is egter moeilik om uit te maak.

Die bedoeling van Romeine 1:20 is blykbaar dat God Hom in sy skeppingswerke vir alle mense kenbaar maak. Van die skepping af tot vandag toe kan God se onsigbare dinge immers in sy werke verstaan en duidelik gesien word. 'n Mens sou byna kon sê: Elkeen met oë kan dit sien en elkeen met begrip kan dit verstaan. Maar in Romeine 2:1-3:8 loop die lyn verder na 'n ander wyse van openbaring waarmee God na die mens toe gekom het - spesifiek na die Jode toe. In 3:2 word gesê dat die Jode 'n groot voordeel bo ander mense gekry het in dié opsig dat

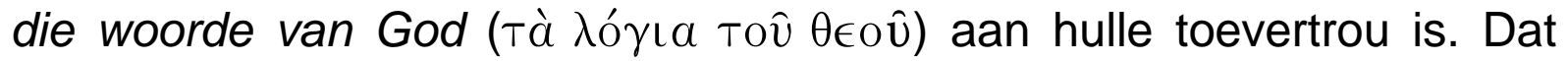

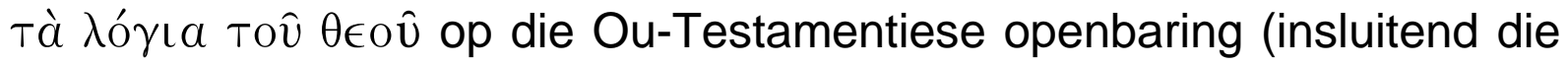
wet) dui, word bevestig deur Romeine 2:17,18: "Jy dra die naam van Jood en steun op die wet en beroem jou op God, en jy ken sy wil en onderskei die dinge waar dit op aankom, omdat jy in die wet onderrig is." In Romeine 2:12-15 word die twee maniere waarop God Homself kenbaar maak, uitdruklik naas mekaar gestel: aan die een kant word Hy geken "sonder die wet" (á $\nu$ ó $\mu \omega s)$, dit wil sê bloot uit sy skeppingswerke; aan die ander kant "in die wet" ('́v $\nu$ ó $\mu \omega$ ), dit wil sê vanuit die woorde wat God aan die Jode toevertrou het.

Maak God in sy skeppingswerke dieselfde dinge bekend as in die woorde van die wet? Uit die bespreking in 3.2.1.1 hierbo lyk dit tog so.

- In sowel die skeppingswerke as die woorde van die wet maak God aan mense bekend dat Hy die almagtige God is aan wie alle eer en dank verskuldig is.

- In albei wyses maak Hy bekend dat Hy in aanbidding gedien moet word deur te doen wat vir God goed en aanneemlik is.

Tog is die wet nie 'n blote duplisering van die skeppingsopenbaring nie. Wie immers die wet ontvang het, het daarmee 'n groot voordeel bo ander mense verkry (Rom. 3:1,2). Die wet, sê Romeine 2:20, is 'n samevatting (oftewel beliggaming, $\mu$ ó $\phi \omega \sigma \iota s)$ van die kennis en die waarheid. Daarmee word gesê dat dit wat implisiet in die skeppingsopenbaring aanwesig is, eksplisiet in die wet uitgespel word (vgl. Black, 1973:59; Dunn, 1988:117), sodat elkeen uit die wet God se wil ken en die dinge onderskei waarop dit werklik aankom (Rom. 2:18). Kruger (2000a:58) som dit goed op:

The Jews received more revelation than the Gentiles. This was the advantage of being a Jew. They also received the revelation which had continued since creation ... The great advantage of a Jew was ... that God communicated more and more clearer to him so that this 
Jew could know God better and his will better than the Gentiles could.

Romeine 4 bied egter nog 'n verdere perspektief op die wet as Godsopenbaring. In Romeine 4:9-13 word nadruklik gesê dat Abraham geglo het sonder dat hy die wet ontvang het. Hieruit sou afgelei kon word dat Abraham niks meer as net die skeppingsopenbaring ontvang het nie en dat Hy bloot op grond daarvan geglo het. So 'n afleiding sou egter nie met die bedoeling van Romeine 4 rekening hou nie. Romeine 4 is 'n teregwysing aan die Jode wat gedink het dat hulle voor God regverdig is bloot omdat hulle die wet ontvang het (vgl. Dunn, 1988:117). Trouens, uit verse 13 en 18-21 blyk dit dat Abraham wel meer as net die skeppingsopenbaring ontvang het. Hy het ook God se belofte ontvang. Abraham, sê Romeine 4:20, het nie in ongeloof aan God se belofte getwyfel nie, maar het aan God die eer gegee en was ten volle oortuig dat God die mag het om te doen wat Hy beloof het. Die eer wat Abraham aan God gegee het en die oortuiging dat God mag het om dit te doen, is in ooreenstemming met God se skeppingsopenbaring. Maar by Abraham is daar méér: hy het ook die belofte wat hy van God ontvang het, geglo.

\subsubsection{Mense onderdruk die waarheid aangaande God}

Uit die staanspoor is dit duidelik dat Romeine 1:18-25 gaan oor mense wat die waarheid onderdruk (1:18). In die res van die perikoop word ook vermeld hoe mense die waarheid onderdruk en waarom hulle dit doen.

\subsubsection{Die maniere waarop mense die waarheid onderdruk}

In die eerste plek, sê Romeine 1:21, verheerlik hulle God nie en dank hulle Hom nie. Dit doen hulle ten spyte daarvan dat hulle God uit sy werke in die skepping leer ken het ( $\gamma \nu$ ó $\nu \tau \epsilon S)$ en dus weet dat alle eer en dank aan Hom toekom (vgl. 3.2.1.1 hierbo). Hulle verruil egter hierdie waarheid vir die leuen en vereer en dien eerder sterflike skepsele (vers 25 ). Dit is ook nie 'n geval van misverstand nie, aangesien God se skeppingsopenbaring nie "neutraal" is nie. In vers 20 word uitdruklik gesê dat sy waarheid van die skepping van die wêreld af in sy werke verstaan en duidelik gesien kan word. Die oortreders is dus skuldig aan blatante en moedswillige onderdrukking (vgl. Calvyn, 1950:56; Murray, 1959:41).

Uit Romeine 2 en 3 is dit egter duidelik dat nie net die heidene die geopenbaarde waarheid aangaande God onderdruk nie. Ook die Jode is hieraan skuldig. Romeine 2:17-24 lê dit die Jode ten laste dat hulle, ten spyte daarvan dat hulle God se wil uit die wet ken, dit nogtans nie doen nie. Op hierdie manier doen hulle God oneer aan (vers 23) en gee hulle aanleiding daartoe dat Hy belaster word (vers 24). Die Jode, nog meer as die heidene, behoort van beter te weet. Maar net soos die heidene is 
hulle aan die waarheid ongehoorsaam (2:8; vgl. Cranfield, 1985:148149).

In Romeine 6 word die tema van onderdrukking van die waarheid nog verder ontplooi, hierdie keer as waarskuwing aan die gelowiges (vgl. Dunn, 1988:305) dat ook hulle gevaar loop om die evangelie te misbruik as verskoning om met sonde aan te hou (Rom. 6:1-2,11-16). Daarmee sou hulle 'n deel van die waarheid van die evangelie onderdruk, naamlik die roeping van vrygespreektes om hulle liggame in diens van God te stel deur heilig te lewe (6:19). Daarom is die laaste hoofdeel van die brief $(12: 1-15: 13)$ in geheel aan 'n paraklese gewy om die verlostes in Christus op te roep tot 'n heilige lewe in diens aan God (vgl. veral Rom. 12:1-2).

\subsubsection{Die redes waarom mense die waarheid onderdruk}

Romeine 1:21 noem twee basiese redes waarom mense die waarheid van God onderdruk: hulle begriplose hart is verduister ('́)

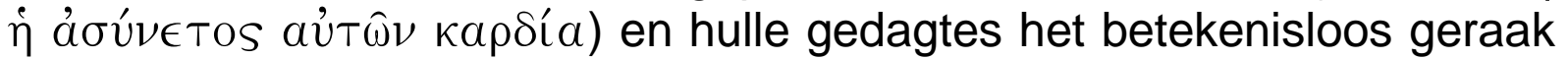

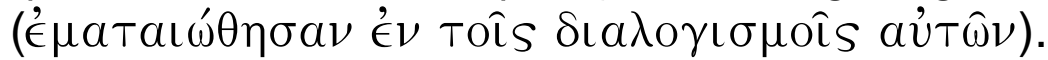

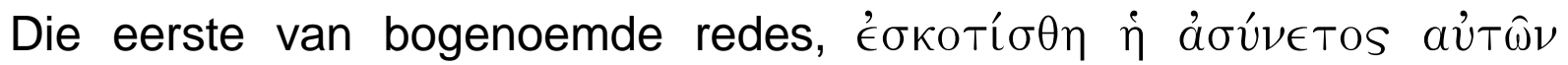

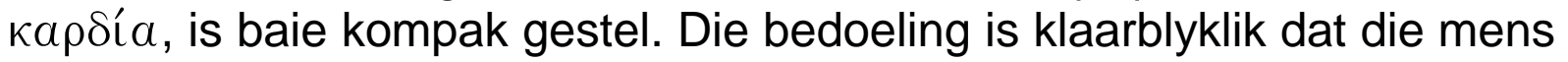
se hart (sy denke, sy hele innerlike wese; vgl. Louw \& Nida, 1988:321) so verduister is (so onbekwaam geraak het om te verstaan; vgl. Louw \& Nida, 1988:386) dat hy verstaanbare dinge nie kan begryp nie

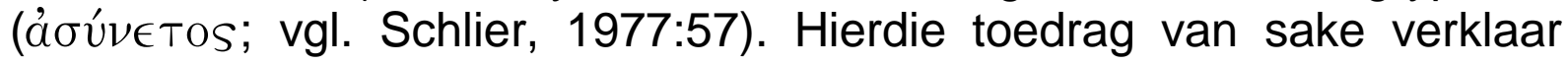
waarom die waarheid van God wat van die skepping af in sy werke verstaan en duidelik gesien word, vir hulle onverstaanbaar en onsigbaar

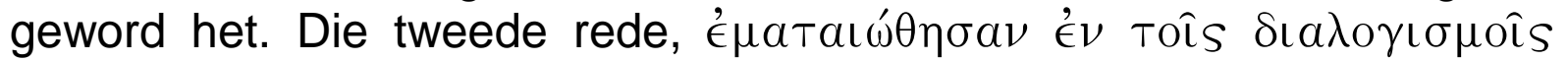
aư $\hat{\omega} \nu$, is waarskynlik die gevolg van die eerste. Omdat die mense onbekwaam geraak het om te verstaan, het al hulle gedagtes betekenisloos en tevergeefs geraak (vgl. Louw \& Nida, 1988:625). Gevolglik verruil hulle die waarheid van God wat so helder voor hulle afgeteken staan vir die leuen (vers 25). So verdraaid is hulle begrip dat hulle, al is hulle dwaas, voorgee dat hulle verstandig is (vers 22). Bý die dwase onderdrukking van die waarheid kom daar dus ' $n$ dwase selfhandhawing en selfverheffing. In ooreenstemming hiermee noem

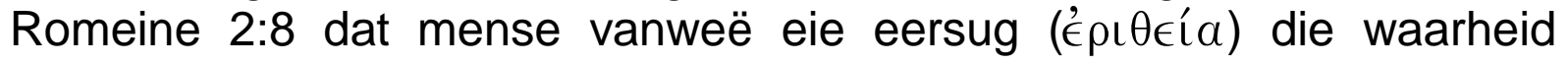
ongehoorsaam is en aan die ongeregtigheid toegee.

Waar kom hierdie ellendige toedrag van sake vandaan? Romeine 1:1825 gee nie 'n verduideliking nie. In Romeine 8:20-21 word die sluier egter effens gelig: "Die skepping is immers nog aan die verydeling onderworpe, nie uit eie keuse nie, maar omdat God dit daaraan onderwerp 
het." Hiermee word die openbaringshistoriese lyn getrek terug na die sondeval en die verydeling wat as gevolg van die mens se ongehoorsaamheid oor hom en die hele skepping gekom het (vgl. Greijdanus 1933:375; Mounce, 1995:185).

God het die mense egter in hulle verduisterde toestand tegemoetgekom. Hy het naamlik sy waarheid ook op 'n ander manier aan hulle bekend gemaak (vgl. 3.2.1.2 hierbo). Aan die Jode het Hy sy wet gegee as beliggaming van die kennis en waarheid (Rom. 2:20) sodat hulle daaruit sy wil kan ken en die dinge waarop dit aankom, kan onderskei (2:18). Tog blyk dit dat die Jode die woorde wat hulle van God ontvang het, nie reg verstaan het nie. Enersyds het hulle gedink dat die blote feit dat húlle die uitverkore ontvangers van die wet was, tot hulle vryspraak voor God sou dien (2:13; vgl. Dunn, 1988:97, 139); andersyds het hulle die eintlike doel van wetsonderhouding misgekyk en dit gesien as 'n manier om self hulle geregtigheid voor God te verdien (9:31; 10:3; vgl. Black, 1973:138).

Waarom het die Jode dan God se woorde verkeerd verstaan? Romeine 2:8, wat vir sowel Jode as nie-Jode geld, gee perspektief: vanweë die eersug ('́fı $\left.\delta \in \epsilon^{\prime} \alpha, 2: 8\right)$ van die verdorwe mens het hulle selfs in die wet rede vir eie roem gesoek (3:27). Daarom het hulle gees in onbegrip vasgevang gebly.

\subsubsection{God se openbaring van die waarheid laat mense sonder verontskuldiging}

Die feit dat God die waarheid aangaande Homself in sy werke duidelik kenbaar aan alle mense gemaak het, ontneem hulle alle verontskuldiging

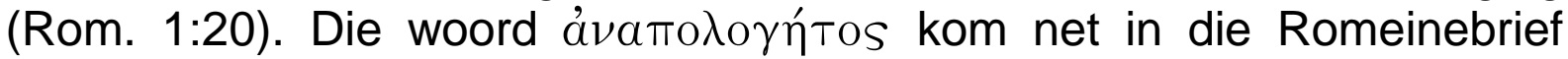
voor, in 1:20 en weer in 2:1. Louw en Nida (1988:435-440) plaas die woord binne die semantiese domein van kommunikasie wat van verdedigende of verskonende aard is (subdomeine 33.435-33.438). Dit is 'n woord wat dus pas binne die konteks van 'n hofsaak.

Hierdie hoofstukke van die Romeinebrief dra besliste trekke van 'n klagstaat wat voor die regbank dien. Trouens, Coetzee (1986:9) stel dat die hele brief die patroon van die destydse hofprosedure volg. Die regbank is God se hemelse regterstoel (1:18; 2:2-10; 3:6). Die aangeklaagde is die hele mensdom, Jode sowel as Grieke (3:9). Die klag is dat hulle in ongeregtigheid die waarheid aangaande God onderdruk (1:18) en God nie soek nie (3:11). Voor hierdie klag staan hulle sonder verontskuldiging (àvaто入оүи́тоs) omdat God sy waarheid verstaanbaar en duidelik sigbaar voor hulle gestel het (1:20). Daarom is die heidene sonder verontskuldiging (1:20) en ook die Jode sonder verontskuldiging (2:1). Die hele wêreld is strafwaardig voor God (3:19). 


\subsubsection{God se toorn en straf kom oor diegene wat die waarheid onderdruk}

Die strafwaardigheid van die hele mensdom lei dan ook daartoe dat hulle God se toorn en straf ontvang. Die perikoop Romeine 1:18 begin juis met die stelling dat die toorn van God (o $\rho \gamma \grave{\eta} \theta \in o \hat{u}$ ) "van die hemel af geopenbaar" word. Die eerste straf wat oor hulle kom, is dat God hulle nog in hierdie lewe oorgee aan hulle eie boosheid en die gruwelike konsekwensies daarvan (1:24, 26-32).

Hierdie tema word in die Romeinebrief verder in twee lyne ontvou, soos in die grafiese voorstelling in afdeling 3.1 aangedui is.

- Die eerste is die (donker) lyn van die sonde-ellende en verdiende straf van die mensdom. Dit begin by die klagstaat teen die mensdom (1:1825 ), word in 2:8 toegespits op die Jode "wat eiesinnig aan die waarheid ongehoorsaam is" en in 2:9 uitgebrei na elkeen wat God se geopenbaarde waarheid onderdruk - Jood sowel as Griek.

- Daar is egter ook die tweede lyn, die genadelyn, wat afwisselend met die eerste ontplooi word en sy klimaks in Romeine 8 bereik. God openbaar nie net sy toorn oor die ongeregtigheid nie, maar Hy openbaar ook dat Hy regverdig maak langs die weg van die geloof.

Dit is opvallend dat die kernbegrip "openbaring van God" in Romeine 1-3 juis volgens hierdie twee lyne (openbaring van sy toorn en openbaring van sy regverdigmaking) ontplooi word:

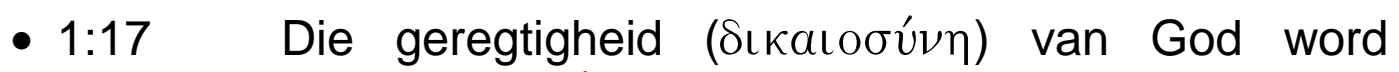

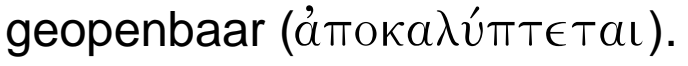

- 1:18 Die toorn van God word van die hemel af

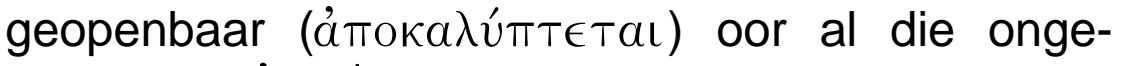
regtigheid (ảsı kía).

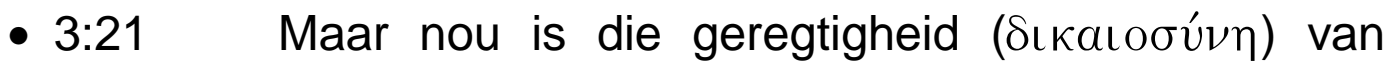

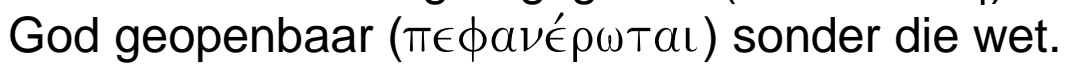

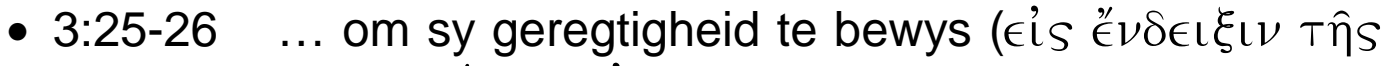

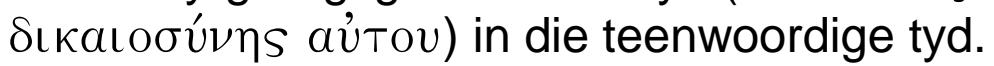

Indien die herhaling van die kernbegrip openbaring in kombinasie met die kernbegrip geregtigheid in 1:17, 1:18 en 3:21 as merkers vir gedagteopbou geneem word, steun dit Kruger se indeling van die eerste hoofdeel van die brief (Kruger, 2000a:45). Die gedagtelyn is kortliks soos volg (vgl. Kruger, 2000a:45): 
A 1:16-17 Temastelling: God openbaar sy geregtigheid in die evangelie as krag tot redding vir elkeen wat glo - Jood én nie-Jood.

B 1:18-19 Verduidelikende stelling: God openbaar sy toorn oor elkeen wat sy openbaring nie glo nie - nie-Jood én Jood.

$\mathrm{C}^{1}$ 3:21 Regstelling: Maar nou openbaar God sy geregtigheid sonder die wet - deur die geloof in Christus.

$\mathrm{C}^{2}$ 3:25-26 Regstelling voortgesit: In Christus stel God sy geregtigheid openlik ten toon as versoening van sondes en as regverdigmaking.

Dit is opvallend dat daar tussen B en $C$ 'n sterk wending kom. Die meeste kommentare verwys na die wending wat deur $\nu \nu \nu \grave{~} \delta \epsilon ́$ ingelei word. 'n Mens kan dit 'n openbaringshistoriese wentelpunt noem. Kruger (2000a:70) verwoord dit soos volg:

With 3:21 Paul comes to the great new era where God has revealed

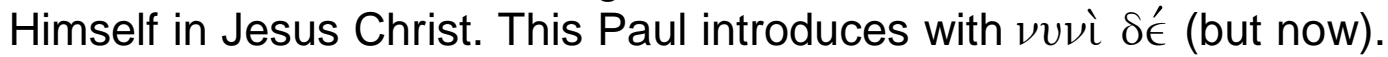
So far he has pictured what happened before the coming of Christ. All people received revelation from God ... but now God comes in his great love with the climax of his revelation in Jesus Christ.

Dit blyk dus dat Romeine 1:18-3:31 in twee groot subafdelings verdeelbaar is: die openbaring van God se geregtigheid vóór Christus (1:18-3:20); die openbaring van sy geregtigheid met/na die koms van Christus (3:21-3:31). Hierdie tweedeling word versterk deur die woorde

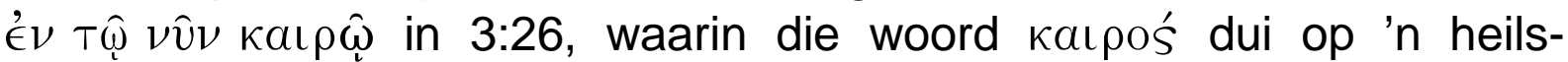
moment wat die oorgang van die vorige na die nuwe bedeling aandui (vgl. Coetzee, 1995b:22).

Ook geplaas binne die raamwerk van die prosedure van 'n hofsitting, is Romeine 3:21 die wentelpunt van die regsproses. Tot op hierdie punt was daar niks wat ter verdediging van die aangeklaagdes gesê kon word

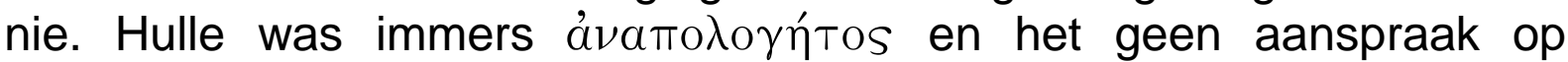
geregtigheid voor God gehad nie. Maar nou is daar 'n ander pleitstaat wat in die regsaak voorgehou word. Dit is dat hulle wat deur die geloof in Jesus Christus is, regverdig gemaak word (3:21-22) omdat hulle die geregtigheid wat Hy verwerf het, uit genade ontvang (5:17-19).

Die hoogtepunt van die regsproses word in Romeine 8:1 gestel, weer eens ingelei deur die partikels ăpa $\nu \hat{v} v$ wat 'n nuwe openbaringshistoriese wendingpunt aandui (vgl. Dunn, 1988:415). Hierdie hoogte- 
punt is die uitspraak wat gelewer word: "Daar is dan nou geen veroordeling (of skuldigbevinding, катáкрı $\mu \alpha$ ) vir dié wat in Christus Jesus is nie." So word die geregtigheid van God waarvan Romeine 1:17 gepraat het, in Christus geopenbaar - "vir elkeen wat glo, eerste vir die Jood en ook vir die Griek” (Rom. 1:16).

\section{Samehang met verwante dele elders in die Skrif}

Die kerntemas wat in die Romeinebrief nagegaan is, hou egter ook verband met verwante dele elders in die Bybel. Ten einde sulke moontlike verbande te bepaal, is 'n opname gemaak van ander Skrifdele waarin dieselfde kerntemas ter sprake kom. Die opname is gedoen deur tersaaklike vakliteratuur te bestudeer en 'n konkordansie-opname van trefwoorde te maak. Daarop is elk van die geïdentifiseerde Skrifdele binne sy onmiddellike en breër Skrifverband geplaas, met inagneming van die plek van die betrokke boek binne die groeiende openbaringslyn van die Skrif vanaf Genesis tot Openbaring.11 'n Samevatting van die neerslag daarvan word hieronder by elke kerntema gegee.

\subsection{God maak die waarheid aangaande Homself bekend}

Op verskeie plekke stel die Bybel dit duidelik dat God wil hê dat alle mense die waarheid aangaande Hom moet ken, want daarin is hulle heil geleë. Reeds in die Ou Testament word dit in Jesaja se profesie van verlossing in vooruitsig gestel: "Laat die nasies kom en hoor en sê: Dit is die waarheid ... sodat hulle kan insien dat dit Ek is" (Jes. 43:9-10). In die Nuwe Testament kom dieselfde tema voor in 1 Timoteus 2:4: "God wil hê dat alle mense gered word en tot kennis van die waarheid kom."

\subsubsection{Dit wat God aangaande Homself kenbaar maak}

Dit is opvallend dat die boek van die skepping, Genesis, self nêrens uitdruklik aandui dat die Here Homself as God, die Almagtige, openbaar nie. Die vraag oor wie God is, kom vir die eerste keer ter sprake in Eksodus 3:13, waar Moses by die brandende doringbos na die Naam van die Here vra en die Here Homself dan bekendstel as "Ek is". Tog word die lyn van God se Selfopenbaring vanuit Nuwe-Testamentiese perspektief teruggetrek tot by die skepping, soos onder andere blyk uit Paulus se Areopagus-toespraak: "God het die wêreld gemaak en alles wat daarin is, ... sodat hulle Hom kon soek, of hulle Hom miskien kon aanraak en vind, al is Hy nie ver van ons elkeen nie" (Hand. 17:24-26).

11 'n Kruiskontrole van die groeiende openbaringshistoriese lyne binne die Skrif kan gedoen word deur 'n vergelykende studie met die samevatting van die Skrifinhoud in die gereformeerde belydenisskrifte. Ruimte daarvoor ontbreek egter in hierdie artikel. 
Ook Paulus se woorde aan die inwoners van Listre bevestig dat God Homself aan alle mense kenbaar maak: "God het Homself nie onbetuig gelaat nie ..." (Hand. 14:17).

Terug by die Ou Testament, blyk dit dat die Here wel aan die nasies bekend maak dat Hy die enige ware God is (vgl. "sy Godheid" in Rom. 1:20), byvoorbeeld die Here se belofte van seën aan Kores: "Ek doen dit sodat elkeen van die ooste af tot in die weste kan weet dat daar buiten My geen God is nie" (Jes. 45:6). Nie net sy Godheid nie maar ook sy ewige krag word in die skepping kenbaar voor alle mense gestel. Daarvan getuig Psalm 89:6-14: "Die hemele loof u wondermag, o HERE ... Wie kan in die hemel met $U$ vergelyk word? ... $U$ heers oor die trotsheid van die see ... aan $U$ behoort die hemel, aan $U$ ook die aarde ... U het 'n arm van mag" (vgl. ook Ps. 86:8-10 en Jes. 43:9-10).

Aan Israel as sy uitverkore verbondsvolk maak die Here Homself duidelik bekend. Die eerste groot moment na sy bekendstelling by die brandende doringbos is by die wetgewing by Sinai: "Ek is die HERE jou God ..." (Eks. 20:2). By Sinai gaan die openbaring verder as net wie Hy is; dit is nou ook die bekendmaking van hoe God gedien wil word (vgl. Durham, 1987:283). Eksodus 20 vorm 'n hoogtepunt in die lyn van die openbaring van God se wil vir die mens, 'n lyn wat begin by Adam (Gen. 1:28: "Wees vrugbaar en vermeerder en vul die aarde, onderwerp dit en heers ..."), wat Noag insluit (Gen. 9:1: "Wees vrugbaar en vermeerder en vul die aarde") en wat 'n nuwe koers inslaan by Abraham (Gen 12:1: "Gaan uit jou land ...").

By die profete in die Ou Testament val die fokus nog sterker daarop dat God Homself in sy dade openbaar. In sy profesie van God se komende oordeel oor die ongehoorsame volk, skryf Amos (3:7): "Die Here HERE doen niks tensy Hy sy raadsbesluite aan sy knegte, die profete, geopenbaar het nie." Later, in Amos 9:11-15, blyk dit dat God se openbaring insluit dat Hy verlossing en herstel belowe (vgl. ook Jes. 40-66; Eseg. 36-48; Amos 9; Sag. 8-11).

Die lyn vanaf die Ou-Testamentiese profesieë na die Nuwe Testament is grootliks (hoewel nie uitsluitlik nie) 'n lyn van belofte-vervulling (Berkhoff, 1971:137-138). In die Nuwe Testament maak God dan ook op verskillende maniere bekend dat die beloofde verlossing en herstel van sy volk sy eintlike vervulling vind in die koms en optrede van Jesus Christus. Die optrede van Christus het tot herstel gelei deurdat Hy vir die mens geregtigheid voor God verwerf het. $\mathrm{Hy}$ is die openbaring van God se geregtigheid (Rom. 1:17; 3:21-24). Vanaf geregtigheid ontvou die openbaringslyn verder na ewige lewe. Om geregtigheid in Christus te ontvang, lei tot die ewige lewe (1 Joh. 1:2). 
Samevattend blyk dit dan dat die Skriflyne oor God se openbaring van die waarheid oor Homself so ontvou dat God bekend gestel word as die enige ware God, die Almagtige wat deur alles en almal verheerlik moet word. Verder maak God sy wil bekend oor hoe Hy gedien moet word en ook hoe $\mathrm{Hy}$ in die geskiedenis met die mens handel. Dit sluit die volgende in:

- God se oordeel oor ongeregtigheid, maar ook die verlossing en herstel wat Hy beloof.

- Jesus Christus wat as die beloofde Verlosser gekom het, het die geregtigheid tot die ewige lewe verwerf vir dié wat glo. Die inligting wat die Romeinebrief bied, kom dus basies ooreen met die breër Skriflyne oor hierdie kerntema.

\subsubsection{Die manier waarop God die waarheid oor Homself kenbaar maak}

Die eerste kenbron waardeur God die waarheid aangaande Homself vir almal kenbaar maak, is sy werke in die skepping. Psalm 19:2 gee dit te kenne: "Die hemele vertel die eer van God; en die uitspansel verkondig die werk van sy hande." Nog duideliker word dit gestel in Handelinge 14:17: "Hy het Homself nie onbetuig gelaat nie deur goed te doen, van die hemel vir ons reën en vrugbare tye te gee en ons harte met voedsel en vrolikheid te vul" (vgl. ook Hand. 17:25).

In die Ou Testament is dit op 'n vroeë stadium reeds duidelik dat God hom in meer as net sy skeppingswerke openbaar. Hy gee ook sy woord as tweede kenbron van die waarheid aan die mens. Sy woorde aan Adam, Noag, Abraham en Moses waarna hierbo verwys is, dien as voorbeelde. Aan Moses gee Hy sy wet sodat die volk sy wil kan ken (Eks. 20:1-17) en aan die profete sy woorde van waarskuwing en belofte. Vandaar die herhaalde oproep aan Israel om te luister na die woorde van die Here (bv. Deut. 4:1; 6:6; Ps. 78:1).

Hebreërs 1:1 gee 'n samevatting van die groeiende lyn van God se openbaring: "Nadat God baiekeer en op baie maniere in die ou tyd gespreek het tot die vaders deur die profete, het Hy in hierdie laaste dae tot ons gespreek deur die Seun." In sy Seun, Jesus Christus, maak God Homself die duidelikste bekend. In hierdie verband geld ook Jesus se woorde in Johannes 14:9: "Hy wat my gesien het, het die Vader gesien." Opvallend in die Johannes-Evangelie is dat die lyn van God se "Ek is"openbaring (Eks. 3:13) na die Christus-openbaring deurloop: "Ek is die brood van die lewe" (Joh. 6:48); "Ek is die goeie herder" (10:14); "Ek is 
die weg en die waarheid en die lewe" (14:6) (ensovoorts, vgl. Coetzee, 1988:57).

In sy laaste onderrig aan die dissipels dui Jesus self aan hoe die waarheid voortaan tot openbaring sal kom. Hy sê: "Wanneer Hy gekom het, die Gees van die waarheid, sal Hy julle in die hele waarheid lei" (Joh. 16:13). Die openbaring deur die Heilige Gees is 'n voortsetting van God se openbaring want, sê Jesus verder: "Wat Hy sê, sal nie van Homself kom nie: Hy sal net sê wat Hy hoor, en Hy sal die dinge wat gaan kom, aan julle verkondig" (16:13). Daarom word die Gees in 1 Johannes as die betroubare Getuie voorgehou: "Dit is die Gees wat getuig, want die Gees is waarheid" (1 Joh. 5:6).

Dit is opvallend dat Jesus die getuienis van die Heilige Gees ook op sy woord betrek. In Johannes 8:32 sê Hy: "As julle in my woord bly, is julle waarlik my dissipels; en julle sal die waarheid ken, en die waarheid sal julle vrymaak." Indien die openbaringshistoriese lyn dan verder gevolg word, tot na Pinkster, en gekyk word hoe die Heilige Gees mense tot die waarheid gelei het, dan dui die geskiedenis daarop dat Hy mense deurgaans tot die waarheid gelei het deur die evangelie aan hulle te laat verkondig (vgl. Hand. 2:14-36; 8:4; 11:19-21, e.a.).

Van die verkondigde woord af loop die lyn van die openbaring van die waarheid verder na die geskrewe Woord. In hierdie opsig is veral 2 Timoteus 3:16 rigtinggewend: "Die hele Skrif is deur God ingegee en is nuttig tot lering, tot weerlegging, tot teregwysing, tot onderwysing in die geregtigheid." Natuurlik is die "Skrif" hier die Ou-Testamentiese geskrifte. Tog is die evangelie van Christus in kiem hierin verteenwoordig, want vers 15 stel dat die Skrifte "jou wys kan maak tot saligheid deur die geloof in Christus Jesus".12."

Samevattend blyk dit dat die Skrifgetuienis aangaande die manier waarop God die waarheid aangaande Homself bekend maak, langs die volgende lyne ontvou: sy werke in die skepping; die woorde van sy wet en sy beloftes deur die profete: sy Seun Jesus Christus; die Heilige Gees; en uiteindelik sy geskrewe Woord. Hiermee word nie verskillende openbarings gegee nie, want dit is een en dieselfde openbaring, maar die manier en die mate waarin die openbaring ontvou word, verskil. Romeine 1:18-25 fokus dan op die eerste van bogenoemde openbaringswyses, naamlik die skeppingsopenbaring, juis omdat dit in dié perikoop gaan oor God se openbaring in die wydste sin en aan alle mense.

12 Die 1983-Afrikaanse vertaling gee dit weer as: “... jou die kennis bybring wat tot verlossing lei deur die geloof in Christus Jesus". 


\subsection{Mense onderdruk die waarheid aangaande God}

In die Nuwe Testament is daar blyke van drie groepe mense wat die waarheid van God verwerp. Daar is diegene wat die waarheid uit die staanspoor verwerp: "Hulle het nie die waarheid liefgehad en tot hulle redding aanvaar nie" (2 Tess. 2:10; vgl. ook Joh. 1:11). Daar is ook mense wat die waarheid aanvanklik ontvang, maar later hulle rug daarop draai (2 Tim. 4:4). Die derde groep is diegene wat die gesonde leer van die apostels verwerp (1 Tim. 6:5, 2 Tim. 2:18 en Jak. 5:19). In Romeine 1:18-25 gaan dit oor eersgenoemde groep, naamlik hulle wat uit die staanspoor die waarheid aangaande God onderdruk het.

Die oorsaak of rede waarom mense die waarheid onderdruk, is volgens Romeine 1:20 hulle verduisterde verstand. Hulle verstaan God se skeppingsopenbaring nie omdat hulle denke as gevolg van die verydeling onbekwaam geraak het. Hiermee word 'n tema voortgesit wat reeds in Jesaja 44:18 gestel is: "Hulle weet nie en verstaan nie, want hulle oë is toegesmeer, sodat hulle nie sien nie; hulle harte, sodat hulle nie verstaan nie." Jesaja 44:18 was gerig op die heidennasies wat beelde in plaas van die ware God aanbid het. Dieselfde lyn word gevolg in Romeine 1:21-23, waarvolgens mense in hulle onverstandigheid die toevlug daartoe neem om beelde van sterflike skepsele te vereer.

Dat die verduisterde verstand die verydelende gevolg van die sonde is, word bevestig deur Efesiërs 4:17-18, wat verwys na die heidene wat "wandel in die verdwaasdheid van hulle gemoed, mense wat verduisterd is van verstand en vervreemd van die lewe van God deur die onkunde wat in hulle is vanweë die verharding van hulle hart." Hierdie verharding van hulle hart verwys na die eiesinnige en moedswillige optrede van die mens sedert die sondeval (vgl. Mitton, 1976:159).

Tog verloop die Skriflyne ook in hierdie opsig van die donker na die lig. God herstel die mens se verlore insig deur die verligtende werking van die Heilige Gees. Die Heilige Gees bring mense daartoe om die waarheid wat God oor Homself kenbaar maak, in die geloof te omhels, soos blyk uit Hebreërs 11:3: "Deur die geloof verstaan ons dat die wêreld deur die woord van God toeberei is, sodat die dinge wat gesien word, nie ontstaan het uit sienlike dinge nie."

\subsection{God se openbaring van die waarheid laat mense sonder verontskuldiging}

Hierbo in afdeling 3.2.3 is reeds aangetoon dat die uitdrukking "sonder verontskuldiging" (ávaто入оүท́тоs) tot die Romeinebrief beperk is. Ook is daarop gewys dat hierdie uitdrukking uit die destydse geregshowe kom. Tog is die wortels van die idee van "geen verontskuldiging" reeds in die 
Ou Testament aanwesig, spesifiek in Job 9. Trouens, die voorstelling van die mens wat voor God soos 'n beskuldigde voor die regbank staan, word dikwels in die Ou Testament gebruik (vgl. byvoorbeeld Ps. 82, Jes.1, Sag. 3). In Job 9 word die klem daarop gelê dat die mens se mond voor God as Regter gesnoer is: "As jy 'n saak teen Hom sou wou voer, sou jy Hom nie eers op een vraag uit duisend kon antwoord nie" (vers 2; vgl. ook vers 14).

Die mens is sonder verontskuldiging omdat God die waarheid oor Homself in sy werke van die Skepping af duidelik kenbaar en sigbaar voor elkeen stel (Rom. 1:20). God se werke in die skepping bly onverpoosd voortduur, soos Handelinge 14:16-17 aandui. Die waarheid oor God is vir alle mense altyd en oral duidelik kenbaar. Daarom roep Hy uiteindelik elkeen hieroor tot verantwoording: "God het dan die tye van onkunde oorgesien en verkondig nou aan al die mense oral dat hulle hulle moet bekeer" (Hand. 17:30).

\subsection{God se toorn en straf kom oor diegene wat die waarheid onderdruk}

God se toorn en straf oor die onderdrukking van sy waarheid word van die sondeval af regdeur die $\mathrm{Ou}$ en die Nuwe Testament verkondig. Hiervan is Psalm 14 'n sprekende voorbeeld. Nadat die goddeloses se gebrek aan verstand ontmasker is omdat hulle nie na God vra nie, word in verse 4 en 5 gewaarsku: "Julle wat weier om die HERE te dien - weet julle dan nie dat daar iets vreesliks gaan gebeur nie?" So word die heidene wat in onkunde oor God geleef het, ook in Handelinge 17:31 tot bekering geroep "omdat Hy 'n dag bepaal het waarop Hy die wêreld in geregtigheid sal oordeel."

Ook in hierdie verband moet daarop gewys word dat in die hele Skrif, net soos in die Romeinebrief, naas die tema van oordeel en straf ook die tema van verlossing en regverdigmaking deur die geloof helder en duidelik ontvou word (vgl. afdeling 3.1 hierbo). Dat God uit genade in Christus aan elkeen wat glo die verlossing tot die ewige lewe skenk (vgl. Rom. 3:21-24), word so by herhaling en op verskillende maniere in die boeke van die Nuwe Testament uitgespel dat 'n bondige oorsig onmoontlik is.

\section{Samevatting tot 'n geheelbeskrywing}

Ten einde bogenoemde oorwegings tot 'n geheelbeskrywing saam te vat, moet die vrae wat aanvanklik gestel is, weer aan die orde kom. Die antwoorde op die vrae is dan terselfdertyd 'n samevatting van die tersaaklike Skrifopenbaring. 
Die eerste vraag wat gestel was, is: Waartoe lei God se skeppingsopenbaring - tot kennis van God self of ook tot saligmakende geloof? Indien Romeine 1:18-25 binne die hele openbaringshistoriese raamwerk van die Skrif gelees word, blyk die volgende:

- Die skeppingsopenbaring dien beslis tot kennis van God. Dit maak aan alle mense duidelik bekend dat Hy die enige ware en almagtige God is wat deur almal vereer en gedien moet word. Dit maak ook bekend hoe God vereer moet word, naamlik deur Hom te aanbid; ook hoe Hy gedien moet word, naamlik deur sy wil te gehoorsaam. Laastens maak die skeppingsopenbaring ook die wil van God duidelik kenbaar.

- Gegewe die situasie voor die sondeval, voor die verderwende werking van die sonde ingetree het, was die mens in staat om God en sy wil so uit die skeppingsopenbaring te ken en Hom in volmaakte gehoorsaamheid aan te roep, te dien en te verheerlik soos dit God welgevallig is.

- Na die sondeval is die mens se begrip so deur sy sondeverdorwenheid aangetas dat hy nie in staat is om die kennis van God reg uit die skeppingsopenbaring af te lees nie. Die ontoereikendheid en ongenoegsaamheid is nie in God se openbaring geleë nie maar in die mens se waarneming daarvan. Die sondaarmens het in homself nie die vermoë om op grond van die skeppingsopenbaring tot die regte kennis van God of tot saligmakende geloof te kom nie.

Die tweede vraag is: Dien die skeppingsopenbaring bloot daartoe dat die mens geen verontskuldiging voor God het nie? Romeine 1:18-25, saam met die geheelopenbaring van die Skrif, bring die volgende na vore:

- Inderdaad dien die skeppingsopenbaring daartoe dat geen mens enige verontskuldiging voor God het nie. In die eindoordeel staan elke mens voor God as Regter om verantwoording daaroor te doen of hy God reg geken, gehoorsaam, gedien en verheerlik het. Die mens sal dan nie onkunde kan pleit nie, aangesien al hierdie dinge in God se skeppingsopenbaring duidelik kenbaar was. Ook sal die mens nie ter versagting kan aanvoer dat hy nie die vermoë gehad het om God se skeppingsopenbaring te verstaan nie, aangesien God al die nodige gawes by die skepping by uitnemendheid aan hom gegee het. Deur sy moedswillige ongehoorsaamheid was die mens self die oorsaak dat sy gawes verdorwe geraak het.

- Tog is die skeppingsopenbaring nie bloot daar net om die mens alle verontskuldiging te ontneem nie. In sy genade stel God die gelowiges 
deur die verligtende werking van sy Heilige Gees immers in staat om sy skeppingsopenbaring beter te verstaan. Vir hulle staan dit dan in 'n direkte verband met die saligmakende geloof wat hulle in Christus ontvang het.

Die laaste en waarskynlik mees kritieke vraag is: Het die mens iets meer as net die skeppingsopenbaring nodig (met ander woorde: ook die Woordopenbaring) om tot saligmakende geloof te kom? Romeine 1:18-25, gelees binne die openbaringshistoriese lyne van die Skrif, bied hierop die volgende lig:

- As die verdorwe toestand waarin die mens sedert die sondeval verkeer in ag geneem word, moet op dié vraag bevestigend geantwoord word. In homself is die mens beslis nie daartoe in staat om op grond van die skeppingsopenbaring tot saligmakende geloof te kom nie. Slegs in die geloof kan die mens immers God se skeppingsopenbaring reg verstaan. Daarom het die mens ten minste ook die verligtende werking van die Heilige Gees nodig.

- Met die aanbreek van die Nuwe-Testamentiese bedeling het Christus as hoogtepunt van God se openbaring na vore getree. Van toe af kan niemand tot saligmakende geloof kom nie tensy die Persoon van die gekruisigde en opgestane Christus in die middelpunt van sy geloof staan. Daarom moet die mens, om God se skeppingsopenbaring reg te verstaan, die Persoon van Christus as sentrum daarvan herken en in die geloof omhels.

- Na sy hemelvaart stuur Christus die Heilige Gees in hierdie wêreld juis om mense tot kennis van die waarheid en daardeur tot geloof in Hom te bring. Die geskiedenis van hoe die Heilige Gees ná Pinkster hierdie geloofwekkende werk tot uitvoer gebring het, dui daarop dat Hy juis deur die verkondiging van die evangelie gewerk het. In die lig hiervan kan die volgende gekonkludeer word: Ja, om tot saligmakende geloof te kom, het die mens bo en behalwe die skeppingsopenbaring ook nodig om die Woord van God te hoor. Of die Heilige Gees ook op 'n ander manier kan werk, word nie in die Skrif vermeld nie. Waarskynlik kan Hy. Niks is vir Hom onmoontlik nie. Maar in hierdie opsig moet 'n mens versigtig wees om nie meer te sê as wat die Skrif sê nie, maar ook nie minder nie. Die veiligste weg is om te bly by wat aan ons geopenbaar is, naamlik dat die Heilige Gees mense tot saligmakende geloof bring deur die verkondiging van die Evangelie. 


\section{Bibliografie}

BERKHOFF, L. 1971. Principles of Biblical Interpretation. Grand Rapids : Baker.

BLACK, M. 1973. Romans. New Century Bible. London : Oliphant.

CALVIJN, J. 1950. Uitlegging van de zendbrief van Paulus aan de Romeinen, vertaald door D.J. de Groot. Amsterdam : Bottenburg.

COETZEE, J.C., red. 1986. Glo - en jy sal lewe! Die brief aan die Romeine vir preeklees en Bybelstudie. Potchefstroom : EFJS.

COETZEE, J.C. 1988. Die teologie van die Johannesevangelie. (In Du Toit, A.B., red. Handleiding by die Nuwe Testament, VI. Pretoria : NG Kerkboekhandel. p. 3772.)

COETZEE, J.C. 1995a. Route map to the Books of the New Testament. Orkney : EFJS.

COETZEE, J.C. 1995b. Keys to God's revelation in the New Testament. Orkney : EFJS.

CRANFIELD, C.E.B. 1985. A critical and exegetical commentary on the Epistle to the Romans. Vol. I, Introduction and commentary on Romans I-VIII. Edinburgh : Clark.

DUNN, J.D.G. 1988. Romans 1-8. Word Biblical Commentary. Vol. 38. Dallas : Word Books.

DURHAM, J.I. 1987. Exodus. Word Biblical Commentary. Vol. 2. Dallas : Word Books.

FITZMEYER, J.A. 1993. Romans. The Anchor Bible. Vol. 33. New York : Doubleday.

GREIJDANUS, S. 1933. De brief van den apostel Paulus aan de gemeente te Rome. Kommentaar op het Nieuwe Testament. Amsterdam : Bottenburg.

KÄSEMANN, E. 1980. Commentary on Romans. Translated and edited by Geoffrey W. Bromiley. Grand Rapids : Eerdmans.

KRUGER, M.A. 2000a. Romans. Ongepubliseerde manuskrip. Pretoria.

KRUGER, M.A. 2000b. The Kingdom of God and those who have not heard the contents of Scripture. Voordrag by die Gereformeerde Teologiese Kongres te Potchefstroom, Augustus 2000.

KUYPER, A. 1909. Encyclopaedie der Heilige Godgeleerdheid III. Kampen : Kok.

LOUW, J.P. \& NIDA, E.A. 1988. Greek-English Lexicon of the New Testament based on semantic domains. New York : United Bible Societies.

MITTON, C.L. 1976. Ephesians. New Century Bible. London : Oliphants.

MOO, D. 1991. Romans 1-8. Wycliffe Exegetical Commentary. Chicago : Moody.

MOUNCE, R.H. 1995. Romans. The New American Commentary. Vol. 27. Nashville : Broadman.

MURRAY, J. 1959. The Epistle to the Romans. New International Commentary. Grand Rapids : Eerdmans.

RIDDERBOS, H.N. 1982. De Theologie van het Nieuwe Testament. (In Klijn, A.F.J., red. Inleiding tot de studie van het Nieuwe Testament. Kampen : Kok. p. 173190.)

RIDDERBOS, J. 1959. Aan de Romeinen. Commentaar op het Nieuwe Testament. Kampen : Kok.

SANDAY, W. \& HEADLAM, A.C. 1911. A critical and exegetical commentary on the epistle to the Romans. ICC. Edinburgh : Clark.

SCHLIER, H. 1977. Der Römerbrief. Herders Theologischer Kommentar zur Neuen Testaments. Band VI. Freiburg : Herder. 


\section{Kernbegrippe:}

algemene en besondere openbaring geloof en openbaring

Romeine 1:18-25

skeppingsopenbaring van God

\section{Key concepts:}

faith and revelation

general and specific revelation

God's revelation in creation

Romans 1:18-25 
